\title{
Get to Know ... Laura Baker
}

\section{Megan Graewingholt}

C hange, often said, is inevitable, while growth is optional. ${ }^{1}$ Originating in Government Documents, Laura Baker, User Experience and Assessment Librarian, has witnessed considerable change in her career and in the library profession. After more than twenty years at Abilene Christian University (ACU) Library, her position has grown to embrace assessment, promote library technology, and support accessibility of government documents through digitization.

Laura began her career as a Government Documents Librarian straight out of library school. In her words, "I thought it was great experience, since all the functions of the rest of the library were contained in government documents." Despite title changes over the years, Laura still enjoys working with government documents and promoting their use. With the current movement towards weeding and born-digital documents, government information work is now "more about where you can find something and how patrons can access it." In this sense, documents digitization and library assessment can go hand in hand.

When it comes to evaluating collection

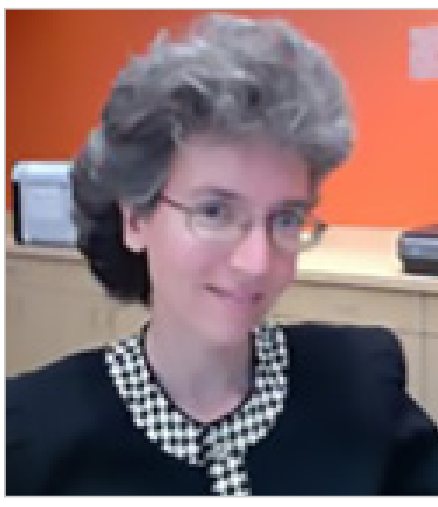

Laura Baker use, librarians everywhere are beginning to see significant focus on data-driven decision making, especially with the increasing demand for library space. In Laura's role in library assessment, her aim is "to determine how well we are meeting the needs of our users. What kind of role do we play and what difference do we make in the teaching and learning process?" While usage data can be helpful in managing collections, she affirms that the center of assessment sits at the ability to gather essential data to tell the story of the library and underscore its value to ourselves and others. While occasionally it can be challenging to think that everything has to quantified, "If measurement and data can shine a light on that story, I would like to know that my efforts are spent in an area that's making a difference."

In her role as User Experience and Assessment Librarian, Laura witnessed first-hand the benefits of incorporating technology into library spaces in ACU Library's makerspace. With a background in computers, she enjoys seeing how technology can interface with library work and create new forms of learning. The ACU Maker Lab thrives as a center of innovation covering a seven-thousand-foot library space with over twenty-three hundred registered users. ${ }^{2}$ It's technology not only supports course curriculum, but formed a community of creators among campus clubs and intermural sports teams. It also demonstrated to Laura how technology can help to empower libraries that don't have a huge staff or a large budget. For many librarians in government documents, staffing and funding can be substantial hurdles in participating in digitization and preservation projects.

Many GODORT members may remember Laura from her recent virtual poster presentation at the fall 2020 Federal Depository Library Conference. Her poster, entitled "No IR? No Problem: The Resourceful Librarian's Guide to Archiving Digitized Government Publications with the Internet Archive," illustrates how librarians with or without an institutional repository can still participate in digitization and preservation programs. This project came from her own experience working with the Internet Archive to help make government documents more accessible for patrons. As Laura pointed out, "It's not as completely intuitive as one might think. I've learned a little bit working with it that I wished I had known getting started... how to put things up, the different metadata fields and what they mean. Being able to promote the tool and at the same time saying here's how you can use it most effectively can be a benefit for everyone." Professional conferences frequently feature presentations from amazing institutions and librarians conducting large-scale digitization programs. Like many, Laura wondered what role she could play. "I'm so excited to be able to find some way we could participate in some small manner and if enough libraries do it, hopefully that will just grow the access even more." Along these lines, even by engaging in small-scale projects, the Internet Archive allows for smaller libraries, with or without an institutional repository, to get involved in documents digitization to support government document discoverability and use.

When it comes to promoting government documents, Laura says, "We spend a lot of time trying to convince people that government documents have good information. I think the real barrier that is keeping so many people from using documents is not the quality of the content, it's what you have to do to find it." Being inclusive, adaptable, and incorporating government information in the searching users are already doing can help to break down some of these barriers. Providing online 
versions of print government documents has been especially essential during the pandemic, when patrons cannot come to the library in person. Rather than just emailing copies of scanned documents, uploading them to the Internet Archive allowed additional online availability. As Laura notes, "It's just a little bit of extra work to put it up, since the scanning is being done already. Then, hopefully anyone else that needs it can have access to it, too." This process became particularly helpful when providing materials for courses using government documents in course assignments. Moreover, when it comes to making decisions for weeding documents from collections, digitization can increase the use of material that otherwise may be sitting on shelves. As Laura reiterates, "Being in the place where people look matters for access." In this regard, digitization and assessment can help to create a more accurate and comprehensive usage story through data.

As a future research interest, Laura is curious how librarians and educators are using government documents within the digital humanities. As Laura states, "Government documents could be used a lot more in history projects and all kinds of research projects in the digital humanities. This may be a new future for government publications and to get researchers more familiar with our collections." Undeniably, digital humanities projects are another new frontier to explore when promoting and using government information. If one thing is clear, in spite of a rapidly changing environment, librarians like Laura are admirably growing the profession by telling the story of documents collections and expanding their visibility and use.

\section{Notes}

1. John C. Maxwell, 15 Invaluable Laws of Growth: Live Them and Reach Your Potential (New York: Center Street, 2012), 85-86.

2. "ACU Maker Lab," Abilene Christian University, https:// makerlab.online/

3. Laura Baker, "No IR? No Problem: The Resourceful Librarians Guide to Archiving Digitized Government Publications with the Internet Archive" (poster presented at the Federal Depository Library Conference, Virtual Presentation, December 2, 2020). https://www.fdlp .gov/file-repository/outreach/events/depository-librarycouncil-dlc-meetings/2020-meeting-proceedings/2020 -fall-federal-depository-library-conference/virtual-poster -presentations/4526-no-ir-no-problem-the-resourceful -librarian-s-guide-to-archiving-digitized-documents -with-the-internet-archive/file

Megan D. Graewingholt (mgraewingholt@fullerton .edu), Social Sciences and Government Documents Librarian, Paulina June and George Pollak Library, California State University Fullerton 